\title{
BERJALAN BERSAMA ALLAH: REFLEKSI THEOLOGIS BERDASARKAN PENGALAMAN ABRAHAM, ISHAK, DAN YAKUB; SUATU PELAJARAN BAGI GEREJA MASA KINI
}

\author{
Morris Ph. Takaliuang
}

\section{PENDAHULUAN}

Untuk mengerti dan mengenal lebih dalam dan kongkret pengalaman 'berjalan bersama Allah,' maka kita dapat menemukannya di dalam pengalaman bapa-bapa leluhur Israel yakni Abraham, Ishak dan Yakub sebagaimana diceritakan di dalam Perjanjian Lama terutama di dalam kitab Kejadian.

Awal mula perjalanan, proses perjalanan, dan akhir perjalanan hidup bersama Allah dari leluhur Israel tersebut dapat menjadi petunjuk dan bimbingan bagi kita pada masa kini, supaya kita juga dapat memiliki pengertian maupun pengetahuan theologis dan praktis tentang bagaimana kita dapat hidup berjalan bersama Allah dan dituntut oleh-Nya dalam segala aspek kehidupan kita.

\section{BERJALAN BERSAMA ALLAH}

Untuk mencapai maksud bahasan tulisan ini, maka penulis menggunakan logika dan urutan berpikir sebagai berikut.

- Allah memilih orang-orang-Nya

- Allah menyatakan diri-Nya kepada mereka

- Allah mengikat perjanjian dengan mereka dan memberi janji-janjiNya

- Pelajaran untuk gereja-gereja masa kini

Dengan cara demikian ini Allah sendiri memulai, meneruskan dan menggenapi rencana-rencana-Nya melalui orang-orang pilihan-Nya. Dan Allah yang sama dan satu juga adanya memberi jaminan dan perlindungan bagi rencana-Nya tersebut agar dapat terlaksana dengan berhasil melalui kekuatan dan hikmat yang diberikan kepada orang-orang pilihan-Nya. Dan semua orang yang telah dipilih, ditetapkan, dan dilibatkan dalam rencana Allah tersebut adalah semua orang yang hidup berjalan bersama Allah di dalam Kristus pada masa kini juga. 


\section{A. Allah Memilih Orang-Orang-Nya}

\section{Sifat Pemilihan Allah}

Sifat atau karakteristik pemilihan Allah adalah 'independen' dan 'rahasia.' Inisiatif untuk menjalankan hidup berjalan bersama dengan Allah di dalam kehidupan orang-orang beriman dimulai dari hati Allah sendiri dan dilanjutkan oleh Allah yang sama di dalam hati dan hidup orang-orang yang diperkenankan-Nya.

Memilih orang-orang yang layak untuk masuk dalam status hidup, gaya hidup, dan kondisi hidup seperti ini adalah mutlak hak prerogatif Allah yang independen.

Pertanyaan yang terus muncul adalah mengapa justru Abraham yang dipilih dan bukan Nahor atau Harun? Mengapa justru Ishak dan Yakub yang dipilih dan bukan Ismael atau Esau? (Kej 11:27)

Ceritera-ceritera tentang bapa-bapa leluhur itu berulang-ulang menimbulkan pertanyaan-pertanyaan seperti itu. Tetapi dalam hal ini, Allah tidak wajib mempertanggungjawabkan kebijaksanaan-Nya. Ia memilih dengan sukarela menurut kedaulatan-Nya dan pertimbangan-Nya sendiri.

Pada hakikat-Nya Allah mempunyai alasan untuk bertindak demikian. Memilih menurut kesukaan-Nya sendiri bagi Allah tidak berarti memilih dengan sewenang-wenang. Allah tidak memandang muka orang, tidak menganakemaskan seseorang sambil menganaktirikan yang lain, sebagaimana halnya apabila manusia memilih orang-orang yang disukainya, melainkan semata-mata berpangkal pada kehendak dan rencanya-Nya sendiri yang masih mengandung segi rahasia Allah sendiri (U1 29:29).

Cerita-cerita bapa leluhur itu berulang-ulang menekankan segi rahasia tadi. Panggilan Allah kepada Abraham diriwayatkan dengan tidak memberitahukan alasannya (Kej 12). Bahwa Abraham bukan seorang "pahlawan" dalam pengertian jasmani ataupun rohani, ternyata dari kelakuannya sewaktu menghadapi bahaya di Mesir (Kej 12:10-20); khususnya yang tertua di antara ketiga benang cerita itu sering memperlihatkan kelemahan para bapa leluhur. Siapakah yang menjadi ahli waris panggilan dan perjanjian Allah kepada Abraham? Menurut adat yang berlaku pada zaman itu tentulah anaknya yang sulung. Tetapi adat itu justru tidak mengikat, apabila Allah memilih orang-orang-Nya, sampai lima kali terjadi "pelanggaran" pada saat-saat yang menentukan. Ismael tidak diperkenankan menikmati hak kesulungannya, tidak juga dalam hal berbagi warisan dengan Ishak, segala-galanya dialihkan kepada adiknya itu (Kej 16; 17:15-27; 21:1-21). Esau harus mengalah terhadap Yakub, yang lahir kemudian daripadanya, bertentangan dengan kemauan ayahnya, dan tidak kurang pula bertentangan dengan perasaan kita yang lebih tertarik kepada 
Esau daripada tipu muslihat Yakub serta ibunya (Kej 27:1-40)! Di antara anak-anak Yakub yang lahir dari Lea, yakni Ruben, si anak sulung, dibelakangkan terhadap Yehuda, adiknya yang paling muda (Kej 29:31-35; 49:2, 8-9) suatu pelanggaran terhadap anak sulung terjadi sekali lagi, waktu Yakub memberkati kedua cucunya anak Yusuf, dengan mendahulukan Efraim daripada Manasye (Kej 48:17-22). Akhirnya Peres diutamakan dari pada Zerah (Kej 38:27-30; Rut 4: 18-22).

Kitab-kitab Perjanjian Baru juga menggunakan keputusan ilahi yang bebas ini. Yesus Kristus dikatakan 'memanggil orang-orang yang dikehendaki-Nya sendiri (Mat 3:13). Waktu mengumpulkan umat-Nya di Korintus, Allah tak memilih orang-orang bijaksana, para bangsawan atau orang-orang kaya, melainkan justru memilih orang-orang yang dipandang bodoh, lemah, dan hina, supaya janganlah manusia memegahkan diri di hadapan Tuhan (1Kor 1:25-31; Yer 9:23). Allah menetapkan menjadi anakanak angkat-Nya 'menurut keputusan kehendak-Nya yang bebas' (Ef 1:5).

\section{Maksud Pemilihan Allah}

Maksud apakah yang ada di belakang pemilihan Allah terhadap Abraham, Ishak dan Yakub sehingga mereka layak mendapat perlakuan istimewa dari Allah?

Tidak lain ialah untuk mengangkat manusia dan keturunannya menjadi lebih tinggi dari segala orang lain supaya diberkati, diberi kemuliaan, dan semarak (Mzm 8:6). Yang tidak ada pada manusia biasa. Kepada Abraham malah diberi gelar sahabat Allah (Yes 4:8).

Namun maksud Allah belum tercapai dengan pemanggilan, pengasingan dan pengangkatan orang-orang-Nya itu. Juga maksud Allah tersebut, belum terwujud dengan pemberian berkat-berkat-Nya kepada mereka. Para bapa leluhur itu tidak hanya mengecap kenikmatan segala pemberian Allah itu saja, tetapi lebih dari pada itu, Allah menggunakan mereka baik dalam pengertian jasmani maupun rohani, agar mereka senantiasa berada di tengah jalan atau berjalan bersama Allah dalam kehidupan setiap hari.

Untuk maksud tersebut, para bapa leluhur itu senantiasa ditantang oleh firman Allah yang menuntut pendengaran, ketaatan, dan kepercayaan kepada mereka. belum tentu mereka selalu dapat memenuhi tuntutan itu. Tetapi biarpun mereka taat atau tidak taat, percaya atau kurang percaya dengan tujuan inilah mereka dipilih dan dipanggil yakni supaya digerakkan dan dibangkitkan sebagai manusia baru.

Selanjutnya, para bapa leluhur itu ditantang oleh firman Allah yang menuntut suatu sikap baru terhadap sesama manusia, mereka tidak hanya digerakkan supaya menaruh kepercayaan kepada janji-janji-Nya dan 
mentaati perintah-Nya. Mereka tidak hanya terpilih untuk menjadi hambahamba Tuhan (Kej 26:24; Kel 32:13; Ul 9:27; Mzm 105:6) di dalam pengertian yang menyangkut sikap mereka terhadap Allah. Justru sikap baru mereka terhadap Allah itu harus terefleksi di tengah-tengah masyarakat bangsa-bangsa, di setiap negeri penumpangan mereka sebagai orang asing (Kej 17:8).

Allah memilih para bapa luluhur itu bukan karena mereka ternyata orang-orang yang baik, benar, dan bijaksana, pelopor-pelopor umat yang dikehendakinya; sebaliknya, sebagai orang-orang yang terpilih itulah mereka ditantang, supaya tetap menuruti jalan Tuhan dengan melakukan kebenaran dan keadilan. Sehinga menjadi suatu tantangan pula terhadap masyarakat di negeri penumpangan mereka. Hanya sekali-sekali dan di dalam arti yang terbatas saja mereka berhasil dalam melaksanakan tugas. Para leluhur itu menjaga dengan hati-hati supaya pujian segala pujian di dalam hal ini diberi kepada Allah dan bukan kepada manusia.

Di dalam Perjanjian Baru, para hamba Tuhan dan gereja Tuhan yang sejati dikatakan sebagai perantau-perantau ataupun pengembara di dalam dunia ini (Yak 1:1). Justru karena itu, gereja mesti memiliki sikap setia dan taat pada panggilan Allah pada satu sisi, dan pada sisi yang lain jemaat harus merefleksikan sikap itu di dalam hubungan dengan orang-orang tak beriman di dalam dunia ini supaya mereka juga memandang kepada Allah yang juga memanggil mereka kepada persekutuan dengan Kristus Yesus (1Kor 1:9).

\section{B. Allah Menyatakan Diri Kepada Mereka}

Allah menyatakan diri kepada para bapa leluhur itu. Sambil "memanggil" dan "menggerakkan" mereka, Dia sendiri tidak tinggal tersembunyi belaka. Tindakan-Nya tertuju kapada manusia yang dipilihNya dan perhatian kita pun diarahkan kepada orang-orang pilihan-Nya itu. Namun di dalam tindakan-Nya ini sekaligus Dia menyatakan diri, sehingga perhatian kita pun terarah kepada Dia yang bertindak. Allah "memperlihatkan" atau "memperdengarkan diri-Nya, atau dengan cara lain menyatakan kehadiran-Nya; tambahan pula, Ia menyatakan siapa Dia yang hadir itu dan "memperkenalkan" diri dengan nama-Nya sendiri.

Jika kita meninjau pokok-pokok kesaksian Perjanjian Lama di dalam keseluruhannya, maka ternyatalah segi penyataan ilahi ini tidak hanya terdapat dalam pokok para bapa leluhur itu saja. Allah menyatakan pada waktu keluaran dari Mesir dan di dalam pokok gunung Sinai pun terdapat segi penyataan ilahi. Semua perbuatan Allah yang menonjol sebagai pokok-pokok kesaksian Perjanjian Lama merupakan - biar dengan cara langsung atau dengan cara tidak langsung - penyataan-penyataan 
tentang Allah sendiri. Namun, sebagaimana tiap-tiap perbuatan Allah mempunyai sifat lain dari pada yang lain, peyataan diri-Nya itu pun mempunyai sifat dan tekanannya yang berlainan tiap-tiap kali; lain di dalam hubungan pokok penciptaan dunia, lain di dalam pokok bapa-bapa leluhur kini, dan tentu sekali lain pula di dalm pokok-pokok yang akan diuraikan kemudian. Dengan ini kita tidak menyangsikan kesatuan Allah di dalam segala perbuatan-Nya dan di dalam segala penyataan diri-Nya; kita hanya menekankan kekayaan-Nya yang membuka segi-segi baru yang ajaib, setiap kali Dia bertindak.

Dengan cara bagaimanakah Allah menyatakan diri? Kitab-kitab Perjanjian Lama pada umumnya, dan cerita-cerita para bapa leluhur khususnya, tidak terikat pada suatu ajaran atau dogma, dan tidak mengemukakan suatu pola atau patokan tertentu. Allah menyatakan diri dengan berbagai cara dan jalan; boleh juga kita katakan bahwa para pengarang memakai berbagai cara untuk meriwayatkan penyataan itu yang seorang dengan cara lebih sederhana, konkret dan langsung; yang lain dengan cara lebih halus, memakai istilah-istilah abstrak dan secara tidak langsung. Perbedaan-perbedaan ini disebabkan oleh latarbelakang para pengarang itu masing-masing, mereka beriwayat sesuai dengan cara yang biasa di dalam kalangan, aliran, zaman masing-masing, namun semuanya meriwayatkan peristiwa yang sama, peristiwa yang semuanya didasarkan sebagai tindakan ajaib Allah.

Ada kalanya Allah dikatakan "menampakkan diri," lalu berfirman kepada para bapa leluhur, tetapi dengan cara bagaimana Dia menampakan Diri tidak dijelaskan sama sekali. Boleh jadi Allah menampakkan diri pada waktu malam, sehingga kelihatan kepada manusia yang sedang tidur dan bermimpi. Lain kali Allah dikatakan menampakkan diri dengan memakai rupa seorang laki-laki; para bapa leluhur itu tidak menyadari, siapa yang dihadapinya, dan baru menjelang akhir cerita itu menjadi terang bahwa mereka telah mendapat kunjungan dari "malaekat TUHAN" atau malah dari TUHAN sendiri.

Di dalam Perjanjian Baru penyataan diri Allah telah dinyatakan secara "sempurna" di dalam Tuhan Yesus Kristus melalui rasul-rasul-Nya serta gereja-Nya sepanjang masa (Gal 1:15-16; Ibr 1:1-3). Kita sebagai tubuh Kristus telah menerima penyataan Allah ini karena Dia sendiri atas rencana-Nya sendiri telah berkenan menyatakan anak-Nya di dalam kita turun-temurun (Mat 11:25-27; Yoh 17:20-21; Kis 2:37-39). 


\section{ALLAH MENGIKAT PERJANJIAN DAN MEMBERI JANJI-JANJI- NYA}

\section{A. Allah Mengikat Perjanjian}

Dalam kaitan yang erat dengan memilih dan memanggil para bapa leluhur itu Allah mengikat suatu perjanjian dengan mereka. Dengan Abraham diikatkan-Nya suatu sumpah setia yang diteguhkan dengan upacara perjanjian dan sumpah itu diperbaharui-Nya kepada Ishak dan Yakub, semuanya sebagai pertanda dan pendahuluan dari perjanjian yang akan diikat-Nya dengan umat Israel pada waktu kelahirannya, yakni pada wakti Dia membawa mereka ke luar dari Mesir. Perjanjian dengan bapa leluhur itu segaligus merupakan perjanjian Tuhan dengan Israel. Di dalam diri Abraham, seluruh Israel diangkat menjadi umat-Nya dan berkenaan dengan diri Abraham, sekali untuk selamanya Tuhan menetapkan diri-Nya sebagai Allah orang Israel.

Kerajaan Israel Utara pernah ditindas oleh tetangganya, kerajaan Siria yang dipimpin oleh Benhadad. Penyusun kitab Raja-rja beranggapan bahwa sudah sewajarnya Israel binasa pada saat itu, namun dengan tak disangka-sangka Allah sekali lagi mengasihani mereka - "karena perjanjian-Nya dengan Abraham, Ishak dan Yakub" (2Raj 13:23). Di sini kita menghadapi suatu pengertian cerita-cerita para bapa leluhur yang melihat perjanjian itu sebagai salah satu unsur yang utama di dalamnya. Suatu pengertian yang bersamaan juga berdiri di belakang Keluaran 2:24 yang berbunyi: "Lalu ingatlah Allah kepada perjanjianNya dengan Abraham, Ishak dan Yakub." Dalam Nehemia 9:8 (di dalam doa Nehemia yang memperingati perbuatan-perbuatan Allah di masa lampau): "Engkau telah mengikat perjanjian itu dengan dia" yakni dengan Abraham. Keluaran 2:24 dan 6:4-5 mengenai satu perjanjian dengan ketiga bapa leluhur itu. Imamat 26:42 malahan mengenal liga perjanjian yang diikat dengan mereka itu masing-masing.

Perjanjian yang diikat Allah dengan Abraham itupun merupakan suatu "lembaga Hukum," walaupun bukannya suatu lembaga yang mengatur kehidupan antar manusia. Menurut hasil-hasil penyelidikan ilmu sejarah bangsa-bangsa sampai sekarang, umat Israel adalah yang pertamatama yang berani berbicara tentang suatu perjanjian, di mana Allah sendiri turut serta sebagai "partner" dan sekutu dari manusia. Bahwa Allah berkenaan mengikat perjanjian dengan manusia, hal ini sudah menjadi begitu "biasa" bagi kita, sehingga jarang sekali kita menyadari betapa ganjil, bahkan betapa "kurang serasi" penggunaan gagasan ini. Sebenarnya tak masuk di akal bahwa Allah dan manusia "bersekutu," menjadi "partner" di dalam suatu lembaga hukum yang mengikat kedua belah pihak! Tak dapat tidak Allah merendahkan diri, dan niscaya pula manusia ditinggalkan, 
apabila dua "pihak," yang begitu berlainan derajatnya masing-masing, sampai dapat bertemu.

Kitab-kitab Perjanjian Lama selalu menekankan "kepatuhan" Allah terhadap lembaga hukum yang didirikan-Nya, namun teranglah bahwa kita menghadapi pengandaian: dengan lembaga ini sebenarnya tidak dimaksudkan lain daripada firman Allah yang mula-mula diberi kepada Abraham, firman yang berupa janji yang kemudian menjadi perhatian kita. Dengan firman-Nya itu Allah membuka isi hati-Nya, menyatakan tekadNya untuk melaksanakan firman itu. Rencana dan tekad inilah yang oleh kesaksian Perjanjian Lama diandaikan sebagai "lembaga hukum" yang berdiri tetap selama-lamanya. Kesetian-Nya kepada "perjanjian" itu dapat dipercayai (bnd. Kej 15:6), itu adalah seolah-olah merupakan suatu "instansi" atau suatu "piagam" yang berkuasa di luar Allah sendiri. "Aku bersumpah demi diriKu sendiri" (22:16, bnd Ibr 6:13:18)!

Di dalam Galatia 3:15-18, 22-29 Rasul Paulus menjelaskan bahwa ikatan perjanjian antara Allah dan Abraham, diteruskan dan diteguhakan di dalam Kristus Yesus dengan gereja-Nya yaitu orang-orang Kristen sepanjang zaman dan sepanjang mereka hidup berjalan bersama Allah di dalam Roh Kudus (Gal 3:15-18, 22-29; Rm 8:1-4, 8-11).

\section{B. Allah Memberi Janji-Janji-Nya}

Dengan perjanjian-Nya yang berupa sumpah setia, Allah mengarahkan pengharapan para bapa leluhur (dan pengharapan umat Israel turun temurun) kepada perbuatan-perbuatan-Nya yang besar di masa depan. Di dalam cerita-cerita Perjanjian Lama mengenai para bapa leluhur, unsur pengharapan ini nampak dari beberapa segi:

1. Di mana-mana disisipkan firman-firman berupa janji mengenai berkat, keturunan dan tanah, yang akan diberi kepada para bapa leluhur dan kepada keturunan mereka

2. Berulang-ulang dijanjikan bahwa keturunan para bapa leluhur itu akan menjadi suatu berkat bagi segala bangsa di bumi

3. Meskipun penggenapan segala janji itu sudah mulai dialami oleh para bapa leluhur, namun penggenapannya yang sesungguhnya berulangulang diperlambat atau ditangguhkan

4. Khususnya di dalam rangkuman cerita Yusuf, janji itu mendekati suatu nubuatan tentang datangnya seorang keturunan para bapa leluhur itu yang akan menjadikan raja keselamatan bagi Israel dan segala bangsa.

Kepada Abraham, Ishak dan Yakub diberi janji-janji yang ajaib. Tanah Kanaan akan menjadi milih mereka untuk sepanjang masa. Keturunan mereka akan menjadi banyak, sehingga tidak terbilang lagi 
jumlahnya, 'seperti bintang di langit dan seperti pasir di tepi laut banyaknya,' bukan hanya satu suku saja akan berasal dari pada mereka, tetapi satu "jemaat bangsa-bangsa." Mereka akan diberkati dengan segala berkat yang dari atas, kesuburan kaum ibu, kesuburan ternak dan kambingdomba, kesuburan tanah milik mereka, kelimpahan hasil jerih payah mereka - semuanya tersimpul sebagai berkat yang berupa penyertaan dan perlindungan ilahi yang tak putus-putusnya. Allah berfirman dan bersumpah bahwa Dia akan melaksanakannya, sebab demikianlah rencana dan kehendakNya yang pasti.

Sejumlah besar dari cerita-cerita leluhur itu memuat kalimat-kalimat dimana Allah menjanjikan tanah, keturunan, dan berkat. Urutan ketiga pokok tentang janji ini berbeda-beda, adakalanya kita hanya menemui dua di antaranya, atau malahan hanya satu saja, tetapi ketiganya tak dapat dipisah, sebab satu pun di antaranya tidak ada artinya jika lepas dari kedua lainnya. Nats-nats yang terpenting adalah (Kej 12:1-3,7; 13:14-16; $15: 5,7,18 ; 17: 4-8,22: 17 ; 26: 3-4 ; 28: 3-4,23-24 ; 32: 13$ [12]; 35:11-12; 50:24; Kel 6:4-7; 32:13). Nats-nats di mana hanya janji tentang tanah itu saja disebut, sebaiknya kita daftarkan sendiri (Kej 12:7; 15:7, 18: 24:7; 50:24; Kel 13:5, 33:1; Bil 10:29; 14:23; 32:11; Yos 1:2-5 dst). Janji tentang kelahiran Ishak (Kej 17:15; 18:10) merupakan bentuk khusus dari janji tentang keturunan.

Untuk janji tentang berkat yang "dipantulkan" kepada bangsabangsa (bnd. Kej 12:2-3 rumus yang terkenal "dengan dia/engkau keturunanmu akan diberkati segala kaum/bangsa di atas bumi" terdapat 5 kali (Kej 12:3; 18:18; 22:18; 26:4; 28:14; bnd. Kis 3:25; Gal 3:8).

Puncak penggenapan janji-janji Allah kepada para bapa leluhur Israel adalah Yesus Kristus. Segala janji Allah diteguhkan di dalam Dia dan melalui Dia diteguhkan oleh gereja dalam "amin" ibadatnya (2Kor 1:20).

Kutipan-kutipan Perjanjian Lama dalam cerita-cerita Injil menunjukkan kepada pemenuhan ini. Nyanyian pujian Maria dan Zakharia menyatakan bahwa Allah telah memenuhi janji-Nya. Firman yang dijanjikan telah menjadi manusia. Perjanjian Baru telah dimulai sesuai "janji yang lebih baik" yang dinubuatkan oleh Yeremia (Yer 31; Ibr 8: 613). Yesuslah jaminannya (Ibr 7:22), dan Roh Kudus yang dijanjikan menjadi buah sulung (Ef 1:13-14). Sambil menunggu janji akan kedatangan kembali Kristus dan langit dan bumi yang baru (2Ptr 3:4, 9, 13), gereja melanjutkan tugas misinya dengan janji akan kehadiran-Nya (Mat 28:20), dan dengan berita bahwa janji Bapa - Roh Kudus (Y1 2:28), diberikan kepada Yahudi dan non Yahudi dalam Yesus Kristus, dan dengan ini dipenuhi janji kepada Abraham tentang diberikannya berkat yang universal melalui keturunannya. Janji itu dihubungkan dengan iman dan terbuka kepada semua orang, yang dengan mengikuti iman Abraham, menjadi 
“anak-anak perjanjian” (Gal 3; Rm 4:9).

\section{PELAJARAN BAGI GEREJA-GEREJA MASA KINI}

\section{A. Bagi Para Hamba Tuhan Masa Kini}

1. Menjadi Hamba Tuhan yang sejati dan teman sekerja Allah di dalam mewujudkan rencana keselamatan Allah untuk dunia ini, adalaj sematamata pilihan dan penetapan Allah berdaulat dan independen. Berdaulat berarti bahwa Allah sendiri dalam kekuasaanNya memilih dan menetapkan seseorang menjadi hamba-Nya. Independen berarti bahwa dalam 'kebebasan' yang mutlak Allah sendiri menentukan seseorang atau beberapa orang menjadi pelayan dihadapan-Nya dan utusan-Nya bagi dunia ini.

Hamba-hamba Tuhan dalam kualitas seperti ini adalah mereka semua yang telah mengerti, mengalami, dan menjalani suatu situasi dan kondisi hidup berjalan bersama Allah dalam dinamika pelayanan setiap hari. Jika tidak berada dalam kualitas seperti ini, seseorang atau siapa saja, adalah sangat tidak layak menjadi hamba Allah yang melayani sesama manusia. Pemilihan dan penetapan Allah saja yang menjadikan kita pantas menjalankan hidup dan pelayanan bersama Allah di dalam dunia ini. Keyakinan dan pengertian akan kebenaran ini harus kokoh dan konsisten di dalam hati dan pikiran kita (Yoh 15:16), karena Allah sendiri yang mengerjakannya dan kemudian kita yang memegang dan mengembangkan-Nya bersama Dia dalam hidup dan pelayanan.

Kita semua tidak dapat menjadi manusia yang hidup bersama Allah dan apalagi melaksanakan kehendak-Nya, jika hal itu hanya merupakan pilihan, keputusan dan tindakan kita semata-mata. Jika hal itu sampai terjadi maka kita adalah pengajar-pengajar palsu, nabi-nabi palsu dan pelayan-pelayan iblis yang menyamar sebagai malaikat terang (2Kor 11:13-15).

2. Pemilihan Allah yang ajaib ini tidak dimaksudkan supaya kita berpangku tangan dan menepuk dada tanda kebanggaan dan kesombongan pribadi karena mendapat hal istimewa di hadapan-Nya, tetapi justru pilihan itu bermaksud supaya kita senantiasa 'berada di tengah-tengah dunia ini' dalam segala persoalan dan kemelut, untuk pada satu sisi hidup berjalan bersama Allah di dalam ketergantungan dan ketaatan yang penuh kepada Dia; dan pada sisi lain kita merefleksikan dan mengaplikasikan cara hidup seperti ini kepada dunia ini dalam bentuk tindakan-tindakan konkrit (presensi, partisipasi, dan 
proklamasi), sebab itulah misi Allah dan misi kita bagi dunia masa kini sampai selama-lamanya.

3. Dan untuk maksud tersebut, Allah terus meneguhkan pilihan-Nya atas kita dengan selalu menyatakan diri-Nya kepada kita melalui penyataan diri Allah lewat firman-Nya/Alkitab. Semakin lama dan semakin jauh kita mentaati Allah karena pertolongan-Nya, juga Allah yang sama senantiasa memperbaharui pernyataan diri-Nya lewat firman-Nya yang kita baca, renungkan dan ajarkan setiap kesempatan dan di sini Roh Kudus yang telah mewahyukan Alkitab untuk memperbaharui pemahaman dan pengertian kita akan maksud dan kehendak Allah bagi kita, bagi gereja-Nya dan bagi dunia ini (2Tim 3:16-17). Dalam hal ini Alkitab selalu menjadi penuntun dan pembimbing hidup dan pelayanan kita dalam segala aspek supaya kita sungguh-sungguh hidup berjalan bersama Allah dalam segala kesempatan.

4. Baik pemilihan maupun penyataan diri Allah kepada kita yang konstan itu, di dalam kasih setia-Nya, diperkokoh lagi dengan diikat-Nya perjanjian setia Allah dan diikuti oleh pemberian janji-janji yang berharga untuk kehidupan dan pelayanan yang benar-benar memuliakan dan membesarkan nama-Nya. Dengan Allah mengikat perjanjian setia kepada kita maka layaklah kita, hamba-hamba-Nya mendapaat bagian dalam kodrat ilahi dan luput dari hawa nafsu duniawi dan penjajahan iblis serta ro-roh jahatnya (2Ptr 1:3; Ef 2:1-7). Sedangkan dengan memberi janji-janji-Nya kepada kita Allah menjamin kehidupan dan pelayanan kita bagi sesama tetap terpelihara, tercukupi dan bahkan berkelimpahan dalam segala kebajikan dan kebenaran (Yoh 10:10; 3 Yoh 1:2-4). Tetapi pada sisi lain kemurahan Allah ini, menantang dan mendorong hamba-hamba-Nya dan gerejaNya untuk terus bertumbuh, berakar dan berbuah di dalam Kristus dalam segala aspek iman kristiani (Kol 2:6-7; 2Ptr. 1:5-11).

\section{B. Bagi Sekolah-Sekolah Theologia Masa Kini}

Sekolah-sekolah theologia yang mengkhususkan diri pada studi Alkitab untuk tujuan memahami kebenaran Allah secara komprehensif telah ada sejak permulaan gereja (gereja rasuli/gereja mula-mula). Dan usaha ini terus berlangsung sampai pada abad pertengahan hingga zaman modern dan pasca modern. Tetapi sejarah menunjukkan bahwa usaha yang gigih untuk memahami kebenaran alkitabiah serta upaya aplikasinya, telah seringkali dinodai oleh berbagai pemikiran, pertimbangan dan pemahaman "filsafat" yang merugikan sekolah theologia tersebut dan menyelewengkan sampai 
menyesatkan theologia gereja Tuhan. Sebagai contohnya, theologia sekolastik yang berpuncak pada Thomisme telah menyelewengkan kebenaran Alkitabiah sampai pada tingkat yang amat dalam sampai-sampai gereja Tuhan selama \pm 1000 tahun (abad ke-5 s/d abad ke-15) tersesat pada jalan dunia ini (filsafat manusia). Dan barulah pada zaman reformasi (abad ke-16) kesesatan itu dikoreksi dan dibaharui secara mendalam dan sistematis.

Namun demikian pada zaman modern dan pasca modern ini bentuk penyesatan terhadap theologia alkitabiah gereja mendapat angin baru dengan munculnya theologia liberal/modern yang pada gilirannya memperkosa kebenaran-kebenaran alkitabiah yang fundamental. Pribadi Kristus dipersoalkan dan diragukan keabsahannya, karya Kristus seperti kebangkitan-Nya dari antara orang mati disanksikan dan bahkan ditolak. Kedatangan Kristus kembali dalam pun tidak luput dari serangan theologia modern, sehingga pengharapan Kristen yang amat fundamental ini diragukan dan tidak layak dipercaya.

Belajar dari pengalaman sejarah perkembangan pemikiran theologia seperti itu, maka pantaslah kita berjaga-jaga, berdoa, dan berusaha untuk membangun dan mempertahankan suatu sistem theologia yang benar-benar kuat dan benar secara Alkitab dan menerapkan dalam sistem pendidikan dan kurikulum sekolah-sekolah theologia masa kini. Kebenaran theologia alkitabiah dimaksud antara lain: sekolah theologia masa kini mesti secara "hikmat Tuhan" memperkokoh dan memperdalam pengertian dan ajarannya tentang pokok pemilihan Alllah, penyataan Allah, ikatan perjanjian Allah dan janji Allah bagi hamba-hamba-Nya, gereja-Nya dan dunia ini secara komprehensif, seimbang, dan benar-benar alkitabiah. Saya yakin bahwa sekolah-sekolah theologia masa kini harus juga berjalan bersama Allah dan pengajaran firman-Nya secara alkitabiah serta menerapkan dalam kurikulum sekolah, pengajaran-pengajaran di sekolah tersebut dan kepada para mahasiswanya secara konsisten.

Dengan pertolongan Allah semata jalan ini dapat kita tempuh dan jalani seumur hidup dan pelayanan kita.

\section{Bagi Orang-orang Kristen Masa Kini}

Pemilihan Allah untuk berjalan bersama Dia, penyataan diri-Nya, ikatan perjanjian dan pemberian berkat-berkat-Nya, pada zaman Perjanjian Baru ini tidak terbatas lagi pada golongan-golongan rohaniawan semata, tetapi Allah dalam kemurahan-Nya dan kedaulatan-Nya telah membentuk suatu partner kerja bagi rasul-rasul-Nya, nabi-nabi-Nya atau murid-muridNya untuk mewujudkan rancangan-Nya pada akhir zaman ini, suatu golongan manusia rohani yang bergelar Imamat orang percaya (1Ptr 2:9). 
Baik rasul-rasul-Nya atau murid-murid-Nya pada satu sisi maupun para imam-imam Perjanjian Baru pada sisi lain, Allah telah mengaruniakan semua kekayaan kemuliaan-Nya kepada kita, agar kita semua baik Yahudi maupun non Yahudi, budak atau merdeka telah diterima di dalam keluarga Allah dan persekutuan dengan Dia dan berita Injil-Nya, supaya kita bersama-sama dan bersatu menikmati segala kekayaan sorgawi itu dan menyampaikan kepada dunia ini agar dunia percaya kepada Kristus dan taat kepada kehendak-Nya (Yoh 17:20-21; Ef 2:12-22).

Oleh karena itu setiap orang percaya kepada Kristus yang berasal dari latar belakang dan status sosial serta golongan apapun mendapat tempat yang pantas dan proposional di dalam keluarga Allah dan kerajaan Allah. Mereka turut mengambil bagian dalam hidup berjalan bersama Allah pada satu sisi, dan pada sisi lain menerapkan cara hidup seperti ini dalam dinamika dan romantika hidup setiap hari. Dan justru inilah tugas gereja dan hamba Tuhan nuntuk mengajarkan cara hidup seperti ini kepada mereka melalui strategi dan program yang relevan, kontekstual, dan efektif. Baik tugas intern ke dalam persekutuan gereja maupun ke luar kepada lingkungan di luar gereja. dan dalam kebersamaan dengan orang-orang percaya kita memenangkan dunia ini bagi Kristus (Mat 28:18-20; Mrk $16: 15-18$; Kis $1: 8)$. 